\title{
Pro-Growth Alternatives for Monetary and Financial Policies in Sub-Saharan Africa ${ }^{1}$
}

\author{
By Robert Pollin, Gerald Epstein and James Heintz
}

\begin{abstract}
I. Introduction
In their IPC Policy Research Brief \#4, John Weeks and Terry McKinley propose major departures from the prevailing neoliberal macroeconomic framework that has dominated policymaking in sub-Saharan Africa. The neoliberal model favours fiscal policy that is preoccupied with maintaining small deficits, monetary policy that is fixated on low inflation targets and exchange-rate policy that is committed to full flexibility.
\end{abstract}

Weeks and McKinley describe an alternative framework with a more expansionary fiscal policy to foster public investment and increase domestic revenues; a managed exchange-rate regime to promote export competitiveness and currency stability; and a monetary policy that supports fiscal expansion and export promotion by achieving low real rates of interest for private investment and the alleviation of public-sector debts.

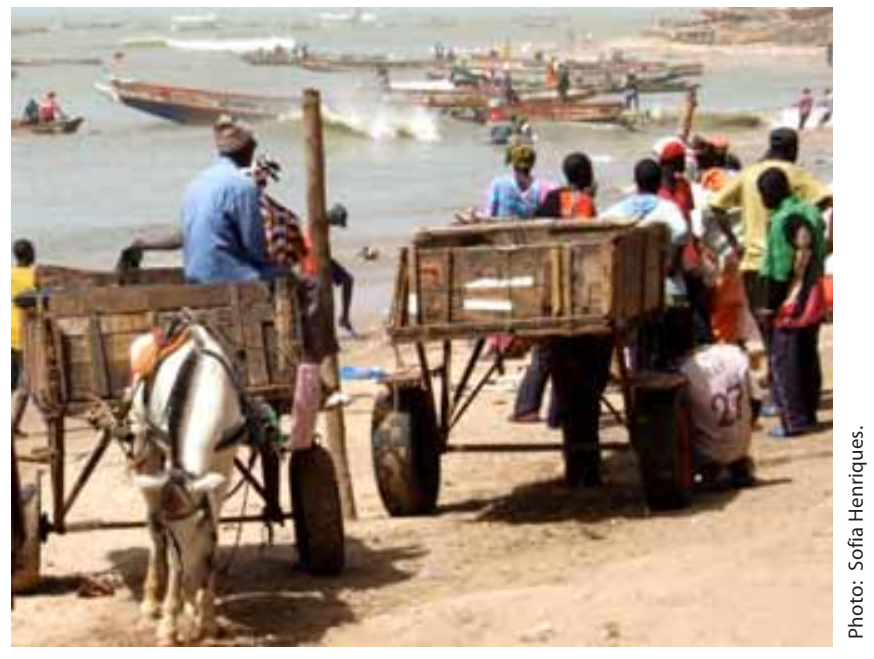

In this complementary Policy Research Brief, we expand on these themes by considering three interrelated issues in further depth: 1) inflation and monetary policy; 2) capital flows, speculation and the exchange rate; and 3) banking systems and access to credit. We show that in each of these areas sub-Saharan African countries can pursue viable alternatives to neoliberalism.

For example, policymakers could take direct measures to dampen the very large inflationary pressures resulting from 'supply shocks' e.g., sharp increases in food and energy prices - as opposed to holding back growth by raising interest rates and trying to contain inflation at five percent or less. Governments could also pursue capital-management policies to reduce exchange-rate volatility. And they could move aggressively to provide increased access to affordable credit, through offering loan guarantees for productive activities and reviving public development banks.

\section{Inflation and Monetary Policy}

Problems with a five-per cent inflation target. The IMF and other global policy-setting institutions strongly support low inflation targets, usually at about a five per cent threshold. Yet there is almost no evidence that holding inflation at such a low level necessarily promotes economic growth (Pollin and Zhu 2006).

Figure 1 (next page) plots the relationship between inflation and economic growth for 25 low-income countries in the world, including 17 from sub-Saharan Africa. A visual inspection confirms what also emerges from a substantial amount of more formal statistical analysis-namely, that there is no evidence that higher inflation, up to 20 per cent per year, correlates with lower economic growth. Note that there is no pattern to the array of data points, even when outliers are eliminated.

Setting the inflation threshold at five per cent creates by itself a slow-growth bias since the primary methods recommended for dampening inflationary pressures are to raise nominal interest rates and cut government spending. Of course, policymakers need to be vigilant about controlling inflation. But they should address this problem by determining the sources of inflationary pressures and whether economic growth and employment expansion could, indeed, benefit from a less restrictive macroeconomic environment.

Our research conducted on 28 sub-Saharan African countries for the period 1975-2005 has found that supply shocks, inertia and exchange-rate depreciations-tied especially to volatile movements of the exchange rate-are the major causes of inflation in the region (Heintz and Pollin 2008).

Supply shocks and inertia. One important example of supply-shock inflation is a rapid rise in food prices due to droughts or other breakdowns in a country's system of food production and distribution. Rapid increases in global oil prices can have similar inflationary effects for the great majority of sub-Saharan African countries that are net oil importers. A sharp rise in food or oil prices exerts upward pressure on other important prices in the economy, such as transportation and electricity prices. 
Figure 1

Inflation and Economic Growth for Low-Income Countries, 1961-2000

Annual data are grouped into 5-year averages

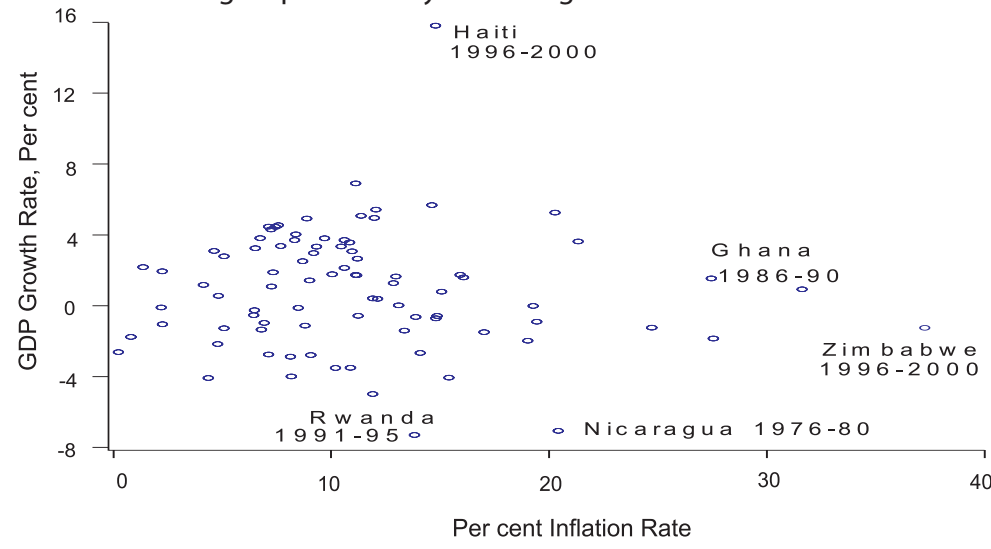

Source: See Pollin and Zhu (2006).

Such price increases tend to persist through an inertial momentum, at least for another year or two. For example, an increase in transportation prices can lead to demands by workers for wage increases to cover their higher living costs. And ensuing wage increases can produce further hikes in transportation costs.

If a government wishes to dampen the effects of food-supply shocks without resorting to significantly tighter monetary policy, it could maintain a buffer stock of strategic grain surpluses that could be released when needed. To dampen the effects of oil price shocks, governments could temporarily raise subsidies for public transportation and electricity rather than allowing the prices of these necessities to build inertial upward momentum.

Exchange-rate depreciations. When a country's currency falls in value relative to that of its trading partners, its exports will become cheaper on world markets but its imports will become more expensive. Sub-Saharan African countries would have to continue purchasing roughly the same level of imports even when import prices rise because of their relatively inelastic demand for such essential items as machinery, chemicals, manufactured goods and oil. Since it is difficult for such countries to produce domestic substitutes even after import prices rise, the inflationary impact can be strong, particularly in the short run.

Hence, it is important to minimize rapid depreciations that can generate such inflationary pressures. We discuss below capitalmanagement policies to promote exchange-rate stability. Over the longer term, countries would have the time to build domestic industries capable of producing substitutes for a rising share of their main imported products.

Monetary Policy Operations. Throughout sub-Saharan Africa, monetary policy focuses on maintaining control over the growth rate of the money supply, narrowly defined mainly as cash reserves in banks (so-called 'M1'). However, this is not a reliable technique because the expansion of the supply of money and credit is strongly influenced by the demand for credit by both domestic and foreign businesses.

Such demand significantly influences, in turn, the rate at which a given supply of bank cash reserves will help expand general economic activity. Because the money supply responds to such forces, the movements of its various measures (e.g., M1, $\mathrm{M} 2$ and $\mathrm{M} 3$ ) are often unstable relative to one another.

We illustrate this instability of monetary aggregates in Figure 2, which shows the relative stock of M1 and M3 for Kenya between 1997 and 2006. M1 rises from only 29 per cent of M3 in 1997 to 45 per cent in 2006. This sharp rise in the relative holdings of $\mathrm{M} 1$ means that the Kenyan Central Bank cannot predict reliably what the market demand for cash reservesi.e., $\mathrm{M} 1$ assets - will be at any given level of economic activity.

Policymakers could be more effective by targeting short-term interest rates as opposed to the growth rate of the money supply. When central banks set the rate at which they lend to private banks, this lending rate will influence, in turn, the short-term rates set by the private sector. Such interest-rate targeting should maintain rates as low as possible in order to expand affordable credit throughout the economy and minimize the servicing of the domestic public debt. Setting the short-term interest rate can also be used to promote a stable and competitive exchange rate.

Figure 2

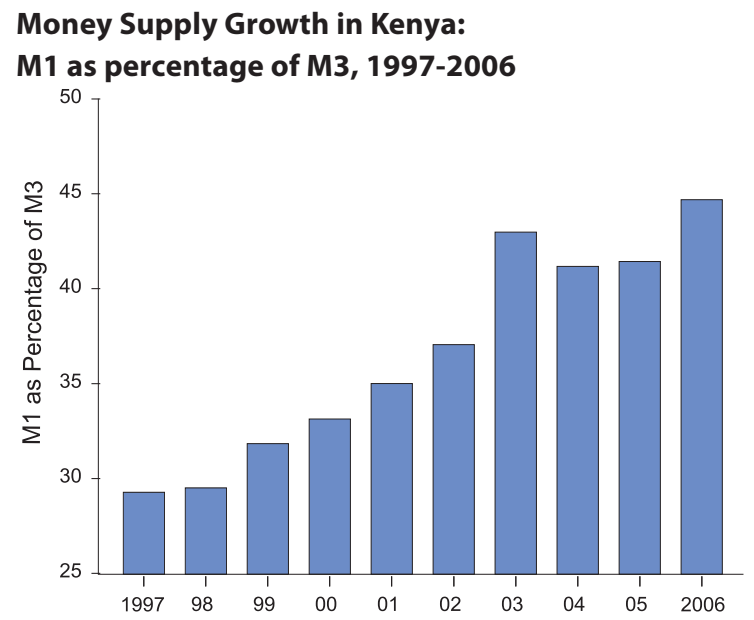

Note: $M 1$ is currency outside banks and total demand deposits. M2 (not shown here) includes M1 plus 'quasi monetary deposits' and non-bank financial institution deposits. M3 includes M2 plus foreign currency deposits.

Source: Central Bank of Kenya.

However, even targeting the short-term interest rate is too narrow for conducting a successful monetary policy in subSaharan Africa. There are two interrelated reasons: a) the problem of excessive speculation and instability in financial markets; and b) the problem of lack of access to credit, especially for small enterprises. We now cover, in turn, these two major issues.

III. Capital Flows, Speculation and the Exchange Rate Exchange-rate management and monetary policy are often seen as operating under a set of constraints. Specifically, it is argued that only two of the following three conditions can hold concurrently: 1) Free movement of capital into and out of the economy; 2) A fixed exchange rate; and 3) An independent monetary policy.

This problem is often referred to as the monetary policy 'trilemma'. Its logic assumes that, given unrestricted capital mobility, a fixed exchange rate can be maintained only if foreign exchange reserves are sufficient to defend the currency against depreciation. So countries often must maintain high interest rates in order to attract enough capital inflows to maintain the fixed rate.

Under these conditions, monetary policy is subordinated to exchange-rate targets-i.e., it is not independent. Similarly, if 
monetary policy is free to set interest rates, the exchange rate must be able to adjust accordingly to ensure a sustainable external balance with the rest of the world. Therefore, an independent monetary policy is often assumed to require a floating exchange rate.

The concept of the trilemma is often used to argue for a relatively market-driven monetary policy and exchange-rate regime. However, the trilemma describes extreme ends of the policy spectrum.

For example, exchange rates that are allowed to float in a managed way ('managed floats') or are pegged loosely to the dollar or other major currencies ('crawling pegs') are intermediate policy initiatives. Since such regimes are not committed to maintaining a fixed rate, there is room for policy intervention for fostering economic growth and employment expansion, especially when governments pursue capital-management initiatives (Epstein, Grabel, and Jomo 2003). For instance, domestic currencies that are loosely pegged to the dollar can have this link weakened when the costs-e.g., maintaining large dollar reserves or otherwise-become too high.

The premise of such capital-management policies is that unrestricted capital flows into and out of a country are not optimal. To date, relatively little attention has been devoted to the use of such policies in sub-Saharan Africa, largely because speculative capital flowing into and out of the region is still relatively modest. However, as African equity and bond markets become increasingly sophisticated, the problems of volatile private capital flows and related exchange-rate uncertainty will worsen.

South Africa provides a useful case study because it has long operated with a well-developed financial sector, and has also operated over long periods of time with innovative capitalmanagement policies (Pollin et al. 2007).

In 1979, South Africa established a dual-currency exchangerate system that was intended to break the direct link between domestic and foreign interest rates, as well as to insulate the country's capital account from certain types of capital flows. A market exchange rate was used for commercial transactions while a separate, less favourable exchange rate, 'the financial rand,' was used for capital transactions.

The dual-currency system, which remained in force until March 1995, was generally effective. A 2001 study by a researcher at the South African Reserve Bank found that the volatility of the rand was lower during the dual exchange-rate period than during the periods of a unified exchange rate. More recent experiences with similar policies in Malaysia, Argentina and other countries of East Asia and Latin America also demonstrate the ways that capital-management policies can be effectively implemented.

\section{Banking Systems and the Access to Credit}

Prominent features of the banking structure in sub-Saharan African economies raise the cost of credit to prohibitive levels and restrict access to credit markets altogether. These problems are particularly serious for small businesses, household enterprises and agricultural small-holders.

The interest-rate spread-i.e., the difference between lending rates and deposit rates-tends to be high throughout the region. The higher the spread, the higher the cost of credit for borrowers for any given deposit rate. A high spread could also indicate that deposit rates are unusually low, which would discourage savings and limit the resources available to finance bank credit.
Figure 3 shows that the average interest rate spread in 2006 for 21 countries in sub-Saharan Africa was 8.9 per cent. The comparable figure for 16 low- and middle-income countries in Asia and Latin America was only 5.3 per cent, while that for the United States was 2.9 per cent.

Figure 3

\section{Average Interest Rate Spreads in 2006}

Interest Spread = Prime Lending Rates - Deposit Rates

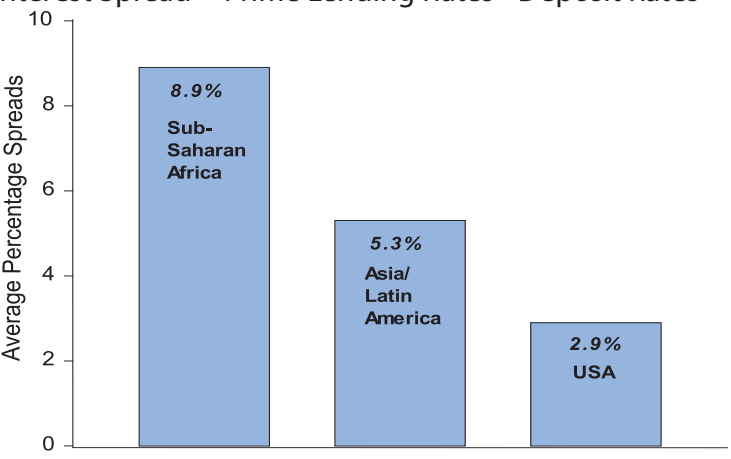

Note: The figure for sub-Saharan Africa is the median spread for 21 countries. That for Asia/Latin America is the median for 16 low-and middleincome countries. The USA figure is the average difference between the prime rate and the 1-month CD rate for 2006.

Source: IMF International Financial Statistics; Board of Governors of Federal Reserve System. See Heintz and Pollin (2008) for details.

Two factors are particularly important in explaining the relatively large spreads in most sub-Saharan African countries (Heintz and Pollin 2008). The first is that, for the most part, borrowers must pay high risk premiums in formal credit markets. This is due to perceptions, often incorrect, that most creditors are high-risk borrowers.

Many commercial banking sectors have never developed the capacity to collect information on the creditworthiness of the potential borrowers who are outside of their traditional clientele. Risk premiums are therefore likely to be particularly high for small-scale and rural borrowers.

The second factor is that the banking system tends to be highly concentrated, with a few large dominant banks. Under these conditions, banks have a degree of market power to raise lending rates and lower deposit rates.

The high cost of bank credit is only one aspect of the credit problem. Often, private businesses have no access to credit, even if they are willing to borrow at the prevailing market rate. That is, credit is rationed. One reason is that banks in the region frequently prefer to hold low-risk assets such as government bonds.

Thus, we find that among 22 sub-Saharan African countries in 2003, the median share of bank credit going to the private sector was only 14.8 per cent of GDP. The comparable figure for nine low- and middle-income countries in Latin America and Asia was 31.8 per cent-i.e., more than double the subSaharan African level.

These limitations of formal financial systems in the region have spurred innovation in informal financial institutions. The informal sector generally operates with greater knowledge of the operations of small businesses, household enterprises and rural smallholders. But since it is seldom integrated into the formal banking system, it tends to have very limited funds.

Overall, financial systems in sub-Saharan Africa operate on the basis of a serious disjuncture: large commercial banks are often unwilling to lend to small enterprises and especially to 
small- and medium-scale agriculture, while informal financial institutions do not have the financial resources to provide significant amounts of credit.

The goal should therefore be to develop effective linkages between the two. For instance, relationships could be built between formal banks and savings and credit associations in order to facilitate group savings and lending for informal and micro-enterprise development. Such initiatives could be tied to credit guarantees and other policies promoting credit allocation.

Pollin, Githinji and Heintz (2008) outline such a programme in Kenya, which has both a well-developed commercial banking sector and the most extensive system of informal microfinance institutions in sub-Saharan Africa. They propose that the government guarantee a significant portion-up to 75 per cent-of loans that commercial banks make to microfinance institutions. This would lower the risks for the commercial banks while infusing the microfinance institutions with enough resources to make a significant difference in promoting smallscale enterprises.

Moreover, to minimize incentives for businesses to defraud the government through this system, the authors propose a system of escrow accounts, to which borrowers and lenders would both contribute. Under this system, they would sacrifice their contributions in the event of fraud or default.

A parallel measure for substantially increasing access to credit for productive purposes in sub-Saharan Africa is to revive the region's public development banks (Pollin et al. 2007). Such banks played a crucial role in nurturing the successes of the East Asian 'tiger' economies, including Japan and the Republic of Korea.

The example of the Industrial Development Corporation in South Africa, the largest such institution in South Africa, is instructive. Its 2005 Annual Report stated that through its lending activity over 2004-05, it anticipated creating 16,700 jobs. But official unemployment in South Africa in 2005 was 4.3 million. Hence, the capitalization of the Industrial Development Corporation needs to increase substantially and it should be allowed to assume a higher level of risk to promote employment expansion.
At the same time, effective performance standards and systems of accountability would need to be developed, as was the case with the successful East Asian development banks. These might include public/private bank lending partnerships or a system of escrow accounts that would create real costs to lenders who were not maintaining their repayment commitments.

\section{Conclusion}

In this Policy Research Brief, we describe several alternatives to neoliberal economic policies for sub-Saharan Africa. We argue that policymakers should pursue specific direct measures to control inflationary pressures resulting from supply shocks and inertia. Monetary policy should then target the short-term interest rate rather than the growth rate of the money supply. Central banks should retain the capacity to concurrently maintain reasonable control over the short-term interest rate and the exchange rate through making judicious use of capitalmanagement policies, such as moderate exchange controls.

Finally, it is imperative for governments to dramatically increase access to affordable credit for enterprises at all levels, including small businesses, household enterprises and rural smallholders. The key policy tools here are large-scale loan guarantee programmes and the revival and recapitalization of public development banks.

The specific proposals that we describe here are well-known and have demonstrated their effectiveness in a range of settings. Taken together, these policies offer a coherent alternative to neoliberalism - that is, they are basic tools for effectively attacking the pervasive problems throughout sub-Saharan Africa of slow long-term growth, mass underemployment and severe poverty.

Robert Pollin, Gerald Epstein and James Heintz

Political Economy Research Institute (PERI)

University of Massachusetts-Amherst.

1. The authors gratefully acknowledge the comments and suggestions of the two external peer reviewers of this Brief: Professor Alfredo Saad-Filho, Head of the Department of Development Studies, and Dr. Costas Lapavitsas, Department of Economics, both of whom are in the School of Oriental and African Studies, University of London. We also thank Terry McKinley, Acting Director of IPC, and Roberto Astorino, IPC Communications Specialist, for their extensive editorial and technical help in preparing this Brief for publication.

\section{References:}

Epstein, Gerald, Ilene Grabel and K.S. Jomo (2003). 'Capital management techniques in developing countries'. in A. Buira, ed., Challenges to the World Bank and IMF: Developing Country Perspectives. London: Anthem Press.

Heintz, James and Robert Pollin (forthcoming 2008). 'Targeting Employment Expansion, Economic Growth, and Development in Sub-Saharan Africa: Outlines of an Alternative Economic Program for the Region'. United Nations Economic Commission for Africa, Addis Ababa.

Pollin, Robert, Mwangi Githinji, and James Heintz (forthcoming 2008). An Employment-Targeted Economic Program for Kenya, Cheltenham, UK and Northampton, MA, USA: Edward Elgar. Available online at: <http://www.peri.umass.edu/fileadmin/pdf/other_publication_types/ Kenya_UNDP_Study_10-27-07.pdf >.

Pollin, Robert, Gerald Epstein, James Heintz, and Léonce Ndikumana (2007). An Employment-Targeted Economic Program for South Africa. Cheltenham, UK and Northampton, MA, USA: Edward Elgar. Available online at: <http://www.peri.umass.edu/fileadmin/pdf/UNDP_S.Africa.pdf>.

Pollin, Robert and Andong Zhu (2006). 'Inflation and Economic Growth: A Cross-Country Non-linear Analysis'. Journal of Post Keynesian Economics 4: 593-614.

The views expressed in this brief are the authors' and not necessarily those of the International Poverty Centre, IPEA or the United Nations Development Programme.

International Poverty Centre

SBS - Ed. BNDES, $10^{\circ}$ andar

70076-900 Brasilia DF

Brazil

povertycentre@undp-povertycentre.org

www.undp-povertycentre.org

Telephone +556121055000

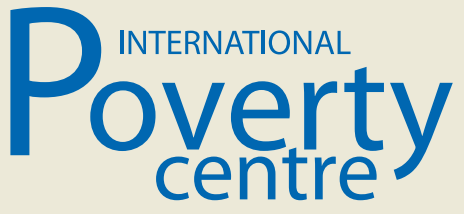

